\title{
CAMA
}

Centre for Applied Macroeconomic Analysis

\section{International spill-overs of uncertainty shocks: Evidence from a FAVAR}

\section{CAMA Working Paper 61/2016 October 2016}

\section{Güneş Kamber}

Bank for International Settlements and

Centre for Applied Macroeconomic Analysis, ANU

\section{Özer Karagedikli}

Reserve Bank of New Zealand

\section{Michael Ryan}

Sapere Research Group

\section{Tuğrul Vehbi}

Reserve Bank of New Zealand and

Centre for Applied Macroeconomic Analysis, ANU

\section{Abstract}

This paper analyses the international spill-overs of uncertainty shocks originating in the US. We estimate an open economy, structural factor-augmented vector autoregression (FAVAR) model that identifies US uncertainty shocks and estimates the impact of these uncertainty shocks on the US economy, major world economies and a small open economy, namely New Zealand. The data-rich nature of our model allows us to investigate different transmission channels from the US to the rest of the world. We find the confidence channels, measured by the expectations surveys, are particularly important in the transmission of the uncertainty shock to a small open economy. 


\section{Keywords}

FAVAR, uncertainty shocks, small open economy

\section{JEL Classification}

C15, C32, E32

\section{Address for correspondence:}

(E) cama.admin@anu.edu.au

\section{ISSN 2206-0332}

The Centre for Applied Macroeconomic Analysis in the Crawford School of Public Policy has been established to build strong links between professional macroeconomists. It provides a forum for quality macroeconomic research and discussion of policy issues between academia, government and the private sector.

The Crawford School of Public Policy is the Australian National University's public policy school, serving and influencing Australia, Asia and the Pacific through advanced policy research, graduate and executive education, and policy impact. 


\title{
International spill-overs of uncertainty shocks: Evidence from a FAVAR*
}

\author{
Güneş Kamber ${ }^{\dagger}$ Özer Karagedikli ${ }^{\ddagger}$ Michael Ryan ${ }^{\S}$ and \\ Tuğrul Vehbi
}

September 27, 2016

\begin{abstract}
This paper analyses the international spill-overs of uncertainty shocks originating in the US. We estimate an open economy, structural factor-augmented vector autoregression (FAVAR) model that identifies US uncertainty shocks and estimates the impact of these uncertainty shocks on the US economy, major world economies and a small open economy, namely New Zealand. The data-rich nature of our model allows us to investigate different transmission channels from the US to the rest of the world. We find the confidence channels, measured by the expectations surveys, are particularly important in the transmission of the uncertainty shock to a small open economy.
\end{abstract}

Keywords: FAVAR; uncertainty shocks; small open economy

JEL: C15; C32; E32

\footnotetext{
${ }^{*}$ We would like to thank the seminar participants at the Reserve Bank of New Zealand, the Bank of Canada and the Southern Workshop in Macroeconomics (SWIM), in particular to Ron Alquist and Christiane Baumeister for their valuable comments. The views expressed here are the views of the authors and do not necessarily reflect the views of the Reserve Bank of New Zealand, Bank for International Settlements and the Sapere Research Group.

${ }^{\dagger}$ Bank for International Settlements and the Centre for Applied Macroeconomic Analysis. E-mail: gunes.kamber@bis.org

${ }^{\ddagger}$ Reserve Bank of New Zealand. E-mail: ozer.karagedikli@rbnz.govt.nz

${ }^{\S}$ Sapere Research Group. E-mail: mryan@srgexpert.com

"Corresponding author: Reserve Bank of New Zealand and the Centre for Applied Macroeconomic Analysis . E-mail: tugrul.vehbi@rbnz.govt.nz
} 


\section{Introduction}

Since the Global Financial Crisis (GFC), there has been a growing interest in understanding the relationship between economic uncertainty and business cycles. The empirical literature finds that elevated uncertainty can account a sizeable portion of business cycle fluctuations. ${ }^{1}$ Most of these studies, however, focus on the impact of domestic uncertainty shocks, mainly in the US context.

This paper contributes to the literature by providing empirical evidence on the international spill-overs and transmission channels of uncertainty shocks. To this end, we develop an empirical model, in which we take New Zealand as a case study, and estimate the effects on the US and New Zealand economies of uncertainty shocks originating in the US. ${ }^{2}$

New Zealand is generally considered to be a text book small open economy. Having a high degree of trade and capital openness and being a price taker on the international commodity markets it exports to, there are numerous channels through which a US uncertainty shock could flow through to affect a small open economy like New Zealand. Our empirical model, an international Factor-Augmented VAR (FAVAR), employs a large macroeconomic dataset from the US, a number of other major economies and New Zealand. ${ }^{3}$

New Zealand's small open status means transmission of uncertainty shocks originating in the US is likely to be unidirectional. We can, therefore, be confident in thinking our foreign (US) uncertainty shocks is truly exogenous and not contaminated by any New Zealand influences; this gives us confidence we are correctly identifying the uncertainty shock in our model. The data-rich nature of the FAVAR allows us to investigate the impact of the uncertainty shock on many different aggregates and prices in a number of countries.

\footnotetext{
${ }^{1}$ Stock and Watson (2012), for example, argue that financial disruptions and heightened uncertainty shocks are the primary cause of the 2007-2009 recession in the US. Leduc and Liu (2016), Alexopoulos and Cohen (2009), Bloom (2009), Bachmann et al. (2010), Baker et al. (2012) all look at how uncertainty interacts with the United States (US) business cycle. By distinguishing between financial and uncertainty shocks, Caldara et al. (2016) find that both shocks played a significant role in the evolution of business cycles in the US. over the past forty years.

2 The existing work on the international transmission of uncertainty shocks mostly focus on the impact of uncertainty shocks on a small set of variables. For example, Mumtaz and Theodoridis (2015) estimate the transmission of the US volatility shocks to the United Kingdom using a six variable structural VAR with stochastic volatility. Chudik and Fratzscher (2011) use a GVAR approach to examine the transmission of US liquidity and risk shocks during the Global Financial Crisis to a number of countries. However, although they are able to use a larger number of countries the number of variables which can be examined in each country is limited.

${ }^{3}$ The FAVAR model, relative to smaller VARs, has the advantage that it is less likely to suffer from omitted variable bias and issues of non-fundamentalness (see Forni and Gambetti (2014))
} 
We find that an uncertainty shock originating in the US causes a persistent decline in real activity and inflation in the US economy. In addition, the uncertainty shock leads to a fall in credit growth and asset prices. In response to the fall in inflation and domestic activity the US policy rate falls. These responses, in particular the dynamics of output and inflation, suggest that uncertainty shocks can be characterised as a negative demand shock in the US as suggested by Leduc and Liu (2016). However our results show that following the uncertainty shock, the US dollar exchange rate appreciates against all major currencies. This is contrary to the dynamics of the US exchange rate following a typical demand shock (Clarida and Gali (1994) and Farrant and Peersman (2006)) and is more consistent with the "flight to safety" type behaviour (McCauley and McGuire (2009)).

The uncertainty shock results in a synchronised fall in economic activity, inflation, stock prices and interest rates across major economies. However, we find more diverse responses in international commodity prices and exchange rates. For example, oil prices fall more than the prices of other commodities such as agricultural goods. Similarly, the exchanges rates responses are relatively less synchronised.

In the case of New Zealand, output, consumption and investment all fall in response to the US-based uncertainty shock. On the inflation side, both tradable and non-tradable inflation decline resulting in lower short-term interest rates. Therefore, the uncertainty shock appears like a global demand shock for a small open economy. We find financial and confidence channels to be more significant than the trade channel. Through making New Zealand's exports cheaper in world price terms, a fall in the New Zealand exchange rate, and a decline in commodity prices in response to the uncertainty shock, appear to moderate the effects on New Zealand's export volumes.

Our paper complements the existing literature on the international effects of uncertainty shocks, by providing a parsimonious way to summarize the interactions between many countries and many variables. Indeed, the existing work on the international transmission of uncertainty shocks mostly focus on the impact of uncertainty shocks on a small set of variables. For example, our paper builds on Mumtaz and Theodoridis (2015)who estimate the transmission of US volatility shocks to the United Kingdom using a six variable structural VAR with stochastic volatility. Chudik and Fratzscher (2011) use a GVAR approach to examine the transmission of US liquidity and risk shocks during the Global Financial Crisis to a number of countries. However, although they are able to use a larger 
number of countries the number of variables which can be examined in each country is limited. Finally, there are recent contributions that employ the FAVAR approach to examine the effects of uncertainty shocks but they only focus on the domestic transmission of uncertainty shocks in the US (Mumtaz and Theodoridis (2016), Popp and Zhang (2016), Caggiano et al. (2014)). Our approach is probably closest to Hirata et al. (2012) who use a FAVAR approach to examine the properties and drivers of house price fluctuations for a number of countries.

The remainder of the paper is structured as follows: Section 2 introduces the empirical framework, and discusses estimation and identification, section 3 presents and discusses the results. Section 4 presents the results of several robustness checks. Section 5 concludes.

\section{Empirical Framework and Data}

\subsection{Estimation and identification}

We estimate the FAVAR model as proposed by Bernanke et al. (2005). We use principal component analysis to extract two sets of factors, domestic $\left(F_{t}\right)$ and foreign $\left(F_{t}^{*}\right)$, from the domestic and foreign datasets respectively. We model the joint dynamics of the extracted factors and the uncertainty index $\left(U_{t}\right)$ by a reduced form VAR as follows:

$$
\left[\begin{array}{c}
U_{t} \\
F_{t}^{*} \\
F_{t}
\end{array}\right]=\beta(L)\left[\begin{array}{c}
U_{t-1} \\
F_{t-1}^{*} \\
F_{t-1}
\end{array}\right]+u_{t},
$$

where $U_{t}$ is a measure of uncertainty, $F_{t}^{*}$ and $F_{t}$ are sets of foreign and domestic factors respectively, $\beta(L)$ is a conformable lag polynomial of order $p$ and $u_{t}$ are the reduced form residuals. The structural disturbances follow $u_{t}=\Omega^{1 / 2} \varepsilon_{t}$, with $\varepsilon \sim N(0,1)$ and $\Omega=A_{0}\left(A_{0}\right)^{\prime}$ where $A_{0}$ is the matrix of contemporaneous coefficients.

We use the Cholesky factorisation of the reduced-form residuals to identify the orthogonal, structural uncertainty shocks. More specifically, we order the variables in the following order: uncertainty measure $\left(U_{t}\right)$, international factors $\left(F_{t}^{*}\right)$ and domestic factors $\left(F_{t}\right)$, which assumes that uncertainty does not respond to the current quarter information contained in the domestic and foreign factors. Furthermore, we impose block exogeneity restrictions such that uncertainty and foreign factors don't respond to NZ factors. Therefore $\beta(L)$ is:

$$
\left[\begin{array}{ccc}
\beta_{11}(L) & \beta_{12}(L) & 0 \\
\beta_{21}(L) & \beta_{22}(L) & 0 \\
\beta_{31}(L) & \beta_{32}(L) & \beta_{33}(L)
\end{array}\right]
$$


We assume that our large dataset can be represented as a linear combination of the latent factors as:

$$
\left[\begin{array}{c}
X_{t}^{*} \\
X_{t}
\end{array}\right]=\left[\begin{array}{cc}
\Lambda^{F^{*}} & 0 \\
\Lambda^{F} & \Lambda^{D}
\end{array}\right]\left[\begin{array}{c}
F_{t}^{*} \\
F_{t}
\end{array}\right]+\left[\begin{array}{c}
e_{t}^{*} \\
e_{t}
\end{array}\right]
$$

where $X_{t}^{*}$ and $X_{t}$ are vectors of observables for foreign and domestic blocks, respectively. $\Lambda^{F^{*}}, \Lambda^{F}$ and $\Lambda^{D}$ are matrices of factor loadings. Finally $e_{t}^{*}$ and $e_{t}$ are vectors of idiosyncratic, zero mean, disturbances. This structure, in particular the matrix $\Lambda^{F}$, ensures that we incorporate the effects of foreign factors in the domestic block. Once we estimate the impulse responses of the factors in response to an uncertainty shock, the factor loadings are used to calculate impulse responses for all variables in our dataset.

We use the approach by Bai and Ng (2002) for determining the number of factors to be estimated from the observed data. Given our relatively small sample size, we include 3 domestic and 5 foreign factors in estimation based on the results from the most conservative AIC3 criteria. $^{4}$

In order to control for the effect of foreign factors on the domestic block, we estimate domestic factors following an iterative approach as in Boivin and Giannoni (2007) and Charnavoki and Dolado (2013). Starting from an initial principal component estimate of $F$, denoted by $F^{0}$, we iterate through the following steps:

1. Regress $X_{t}$ on $F_{t}^{0}$ and foreign factors $F_{t}^{*}$ to obtain $\lambda_{F}$.

2. Compute $\widetilde{X_{t}}=X_{t}-\lambda_{F} * F_{t}^{*}$ to eliminate the contemporaneous effects foreign factors on $X_{t}$.

3. Estimate $F_{t}^{1}$ as the first K-5 principal components of $\widetilde{X}_{t}$.

4. Back to 1

We estimate the model by Generalised Least Squares (GLS) for the period 1995Q1-2015Q2 using two lags.

\section{$2.2 \quad$ Data}

We use quarterly data covering the period 1995Q1 to 2015Q2. The sample size is constrained by the data availability outside the US. The dataset is divided into two blocks: international and domestic blocks. The international block is composed of data from the

${ }_{4}^{4}$ Results are available upon request 
US and other major world economies such as Australia, Canada, China, Japan, the UK, Switzerland and the Euro area. For the US, we use an updated version of Bernanke et al. (2005) dataset. ${ }^{5}$ We also include various measures of commodity prices in the world block. Overall our international dataset comprises 205 individual data series.

The domestic (New Zealand) block comprises a detailed dataset including disaggregated GDP components, prices and survey data, as well as a range of financial variables. In total, we have 115 individual data series for New Zealand which allows us to explore the alternative transmission channels to New Zealand economy in detail. ${ }^{6}$

Our baseline uncertainty measure is based on Jurado et al. (2013). More specifically, we use the financial uncertainty measure they construct as the volatility of the purely unforecastable component of the future values of a large number of financial variables. Jurado et al. (2013) find that their measure differs substantially from other commonly used measures of uncertainty and argue that their measure is a better proxy than other measures imply.

However, there is no agreement about an ideal measure of uncertainty. Figure 1 shows some of the commonly used measures of uncertainty in the literature. We also estimate and plot the first principal component estimated from the five measures. It can be seen that all measures show a general countercyclical pattern and rise during major economic disruptions such as the Asian crisis and the recent global financial crisis. In section 4, we check the robustness of our results by using a number of these alternative measures and the principal component measure of uncertainty.

[Figure 1 about here.]

\section{Empirical Results}

In this section, we present the results from our estimation. Section 3.1 presents and discusses the estimated factors. Section 3.2 presents impulse responses of the US variables to our baseline measure of uncertainty. Sections 3.3 and 3.4 present the impulse responses for the rest of the world and the New Zealand variables respectively.

\footnotetext{
${ }^{5}$ This dataset includes 116 individual data series covering a broad range of macroeconomic and financial variables. We use data from various sources including national statistics agencies. Most of the data is retrieved using HAVER.

${ }^{6}$ Table 2 in the appendix lists all the data used in the estimation as well as the transformation applied to each raw data. All variables are demeaned and standardised prior to the estimation.
} 


\subsection{Factors}

Figure 2 plots the estimated factors. We remain agnostic about what the factors represent aside from splitting them into foreign and domestic blocks.

[Figure 2 about here.]

It is, however, informative to see how much of the variance in some key series are explained by the factors using the R-squared, which is shown in table 1 .

[Table 1 about here.]

For quarterly growth in GDP the factors explain as little as $12 \%$ for Australia to around $71 \%$ for the Euro area; with the R-squared for Canada, U.K. and US all being in the high-50s or 60s. A considerable proportion of world commodity prices is explained by the factors $(88 \%)$, which is encouraging given this is a likely channel through which an uncertainty shock would be transmitted to New Zealand. Furthermore, $69 \%$ of the variance in the oil price, a key variable in the global economy, is explained by the factors. The heterogeneity of R-squared numbers we observed across countries for GDP is also present for nominal exchange rates and inflation. Our factors generally explain between $30 \%$ and $75 \%$ of individual country exchange rates, with the exception of the Euro Area where they only explain 17\%. Japan (20\%), along with Australia (28\%), is also on the outlier for inflation, with the R-squared for inflation in the other countries generally being between $40 \%$ and $80 \%$. The R-squared for short-term interest rates ranges between $42 \%$ for Japan and $95 \%$ for the US.

New Zealand factors explain significant portion of the variance in 90 day rates, GDP, unemployment rate and the exchange rate; the R-squared on inflation is also reasonably high at $59 \%$. These reasonably high R-squared values give us a degree of comfort that the domestic factors are capturing the New Zealand economy well.

\subsection{Impulse responses - US Economy}

Figure 3 shows the impact of a one standard deviation shock to the level of uncertainty on key US variables.

[Figure 3 about here.] 
Following the shock, we observe a statistically significant decline in activity where GDP falls by around 0.1 per cent and unemployment rate increases by approximately 0.15 percentage points. The responses of GDP and unemployment remain significant for approximately one and two years respectively.

The components of the GDP show a similar response; both consumption and investment fall persistently. Durables consumption, which can potentially be deferred by consumers relatively easily, falls more than the consumption of services. However, the fall in consumption services is more persistent. Both residential and non-residential investment decline although the impact is more persistent for non-residential investment. On the capital input side, capacity utilisation also falls with a hump shaped response where the response peaks around 5 quarters. Inflation also falls, reflecting the downturn in economic activity. As a result of falling inflation and reduced economic activity, the US interest rates decrease by approximately 20 basis points. These results are in line with those obtained by Caggiano et al. (2014).

On the financial side, asset prices in the US respond significantly to the uncertainty shock. The stock market exhibits the sharpest fall in response to the uncertainty shock which falls by approximately 1.5 per cent. As discussed in section 3.3, the significant response of US stock prices is consistent with the responses of the stock prices around the world. Reflecting the slowdown in residential investment, house prices respond negatively to the uncertainty shock falling by around 0.1 per cent within a few quarters. The BAA corporate bond spread over the Fed funds rate increases by approximately 15 basis points indicating that the increased uncertainty leads to agents facing a higher risk premium on their borrowing.

US dollar exchange rate appreciates in response to the uncertainty shock which is consistent with a model of international risk sharing, where a shock to consumption in the US (brought about through more household saving owing to precaution owing to increased uncertainty) would see an appreciation in the exchange rate to make imported consumption goods cheaper. Alternatively it is consistent with the common perception in financial markets that the US dollar is a safe haven currency and thus in times of increased uncertainty capital flows out of currencies perceived to be more risky to the US dollar.

Leduc and Liu (2016), on the basis of their DSGE and VAR modelling, concluded that uncertainty shocks in the US act like aggregate demand shocks. Our model yields similar results for output, inflation and labour market variables. However, the exchange rate 
appreciation and the increase in the corporate bond spreads are not fully consistent with an aggregate demand shock interpretation. A typical domestic demand shock would have yielded a depreciation in the exchange rate.

\subsection{Impulse Responses - World Economy}

Figure 4 shows the responses of key variables to a one standard error shock to the uncertainty index. The increased uncertainty leads to contraction in activity across all major economies. Consequently, inflation falls in all countries and monetary authorities respond by lowering interest rates.

The world economy also experiences an immediate and synchronised fall in stock prices. The fall in stock prices in the world economy is comparable to those of the US stock prices. World commodity prices decline for all commodity groups. Oil price shows the largest fall followed by the fall in the price of metal commodities. The decline in the price of agricultural raw materials is relatively more subdued. The differences in the magnitudes of the commodity price responses seem to reflect the different income elasticities - agricultural products, which typically have a low income elasticity, are more affected than metals and oil.

Exchange rates depreciate in all countries except the US, Japan and Switzerland. The behaviour of exchange rates in the latter group of countries is consistent with their reserve currency status and the he flight to safety behaviour commonly observed during uncertain times.

[Figure 4 about here.]

\subsection{Impulse Responses - New Zealand Economy}

Figures 5-7 show the responses of selected variables for the New Zealand economy to uncertainty.

In response to the uncertainty shock the real activity declines in New Zealand. The real GDP growth, consumption and investment all fall in response, with investment falling the most. Unemployment rate increases by approximately 0.2 per cent. The increase in the unemployment rate persists for around 9 quarters. The capacity utilisation falls significantly in response to the shock and return to its pre-shock level after 2 years following 
the shock. Both tradable and non-tradable inflation fall where the fall in tradable inflation can largely be attributed the fall in oil prices.

While the fall in world output acts as a drag on New Zealand exports, there are also a number of offsetting effects that lead to an increase in exports. The depreciation of the New Zealand dollar and the fall in commodity prices contribute positively to the export growth. Imports, on the other hand, decline due to lower economic activity and the lower exchange rate resulting in an improvement in the trade balance.

Figure 6 shows that New Zealand dollar exchange rate falls against every major currency (in a trade weighted sense). The largest falls in the New Zealand dollar occur against the US dollar and Japanese yen, which is consistent with increase in risk aversion during highly uncertain times as investors substitute away from small country currencies such as the New Zealand dollar. For example, at the height of the global financial crisis in 2008, and following the 9/11 events, the New Zealand dollar, along with many other currencies, depreciated significantly against the US dollar. The fall in the New Zealand dollar is also related to the fall in the commodity prices. The commodity currency nature of the New Zealand and the Australian dollars probably explain the relative stability of the New Zealand dollar against the Australian dollar. ${ }^{7}$

[Figure 5 about here.]

[Figure 6 about here.]

Figure 7 shows the responses of macro-financial and expectations/confidence variables in the New Zealand economy. On the macro-financial side the fall in the credit growth is very persistent and peaks around six quarters. In line with falling prices and lower demand, interest rate falls. The magnitude of the interest rate fall is similar to the falls in other advanced economies. Despite falling interest rates, all asset prices and credit falls sharply. Figure 7 suggests that the dynamics of expectations can be important in understanding the macroeconomic dynamics in New Zealand. Both QSBO (Quarterly Survey of Business Opinions) and RBNZ based survey measures indicate that economic agents' expectations about future activity sharply deteriorate. In particular, there is striking conformity between the dynamics of expected unemployment based RBNZ survey

7 It should be noted that the New Zealand/Australia exchange rate is one of the most stable pair of freely floating currencies, whose relative peak to trough variance is around one third of that of the New Zealand/US dollar exchange rate for example. 
and actual unemployment dynamics following the uncertainty shock. Expected and actual GDP also follow somewhat similar patterns. The falls in survey measures without a corresponding fall in exports, suggest that confidence channels are particularly important in the transmission of uncertainty shocks.

[Figure 7 about here.]

\section{Robustness}

We examine the robustness of our results from two perspectives. First, we investigate whether our results are robust to using other measures of uncertainty that are commonly used in the literature. Second, we compare our results with the effect of uncertainty shock derived from a small-scale two country structural VAR.

\subsection{Alternative measures of uncertainty}

We check the robustness of our findings to three alternative measures of uncertainty. The first measure we consider is the implied volatility index of SP 500 (VIX). VIX has been particularly popular in studies investigating the impact of uncertainty shocks and enables us to compare our results directly to these studies. As the second measure, we use the Economic Policy Uncertainty Index suggested by Baker et al. (2016). We construct our third measure as the first principal component obtained from the five alternative measures of uncertainty that are commonly used in the literature. These measures comprise the VIX index, Bloom's uncertainty index, the Michigan Survey, our baseline measure by Jurado et al. (2013) and the forecast disagreement which constructs a measure of uncertainty as the per cent difference between the 75 th percentile and the 25 th percentile of the 1 quarter ahead projections for the quarterly level of the US GDP (see Figure 1).

The results shown in Figures 8 and 9 indicate that our results are fairly robust to using alternative measures of uncertainty.

[Figure 8 about here.]

[Figure 9 about here.] 


\subsection{Comparison with a small-scale VAR}

In this section, we document the effect of uncertainty shock derived from a small-scale two country structural VAR. The VAR comprises a subset of the variables used in the FAVAR analysis namely the uncertainty index (approximated with Jurado et al. (2013)), the US and New Zealand unemployment rates, inflation rates, interest rates and the New Zealand/USD exchange rate. We impose block exogeneity to prevent New Zealand variables having an impact on the US variables. Similar to our model specification, we order the uncertainty index as the first variable followed by the US and New Zealand variables and identify the uncertainty shock recursively using a Cholesky identification scheme.

Figure 10 plots the responses of each variable in the VAR to a one standard deviation shock to uncertainty. Overall, the results are qualitatively similar to the ones we obtain from FAVAR although we observe some sizeable differences in the magnitudes of the responses. We also find that the response of New Zealand's inflation obtained from the simple VAR is not statistically significant. The results confirm that the identified transmission channels are sensitive to the information contained in the VAR.

[Figure 10 about here.]

\section{Conclusions}

We study the transmission of uncertainty shocks originating in the US to several major advanced economies, including New Zealand, by means of a FAVAR. The data-rich nature of the FAVAR enables us to examine the effects on a number of countries and to disentangle the role of different transmission channels. We find that the uncertainty shock has a demand-type effect on the US economy with activity, inflation and interest rates all falling. However, the increase in the US dollar exchange rate and the corporate bond-spreads in response differentiate the uncertainty shock from a typical demand shock.

Following an uncertainty shock, we observe a scyhronised fall in economic activity, inflation, stock prices and interest rates in every major economy in our sample. However, we observe a much less synchronisation in the responses of commodity prices and exchange rates: Although all commodity prices fall, oil and metal prices fall more relative to agricultural commodity prices. While the exchange rates of the commodity currencies 
(Australia, New Zealand and Canada) fall, not every currency depreciates in our sample. Consistent with their safe-haven status, the exchange rates of the US, Switzerland and Japan appreciate.

In the case of New Zealand, economic activity and (GDP, consumption and investment) inflation fall and unemployment rate rises. New Zealand dollar exchange rate depreciates consistent with the decline in the economic activity, and the fall in commodity prices. From a policy perspective, the dynamics of inflation and output do not present a trade-off from a monetary policy perspective especially in an inflation targeting framework. We find a smaller role for the trade channel on the transmission of uncertainty shocks to New Zealand. On the other hand, we find that financial variables such as exchange rates, longterm interest rates and stock prices, and the confidence measures play a relatively larger role in transmitting the uncertainty shock.

\section{References}

Alexopoulos, M. and J. Cohen (2009). Uncertain times, uncertain measures. Working Papers 352, University of Toronto, Department of Economics.

Bachmann, R., S. Elstner, and E. R. Sims (2010). Uncertainty and economic activity: Evidence from business survey data. NBER Working Papers 16143, National Bureau of Economic Research, Inc.

Bai, J. and S. Ng (2002). Determining the number of factors in approximate factor models. Econometrica $70(1)$.

Baker, S. R., N. Bloom, and S. J. Davis (2012). Has economic policy uncertainty hampered the recovery? In L. E. Ohanian, J. B. Taylor, and I. J. Wright (Eds.), Government Policies and the Delayed Economic Recovery, Book Chapters. Hoover Institution, Stanford University.

Baker, S. R., N. Bloom, and S. J. Davis (2016). Measuring economic policy uncertainty. The Quarterly Journal of Economics.

Bernanke, B., J. Boivin, and P. S. Eliasz (2005). Measuring the effects of monetary policy: A factor-augmented vector autoregressive (FAVAR) approach. The Quarterly Journal of Economics 120(1). 
Bloom, N. (2009). The impact of uncertainty shocks. Econometrica rry(3).

Boivin, J. and M. P. Giannoni (2007). Global forces and monetary policy effectiveness. In International Dimensions of Monetary Policy. National Bureau of Economic Research, Inc.

Caggiano, G., E. Castelnuovo, and N. Groshenny (2014). Uncertainty shocks and unemployment dynamics in U.S. recessions. Journal of Monetary Economics 67.

Caldara, D., C. Fuentes-Albero, S. Gilchrist, and E. Zakrajšek (2016). The macroeconomic impact of financial and uncertainty shocks. European Economic Review.

Charnavoki, V. and J. J. Dolado (2013). The effects of global shocks on small commodityexporting economies: Lessons from Canada. American Economic Journal: Macroeconomics (1).

Chudik, A. and M. Fratzscher (2011). Identifying the global transmission of the 2007-2009 financial crisis in a GVAR model. European Economic Review 55, 325 - 339.

Clarida, R. and J. Gali (1994). Sources of real exchange-rate fluctuations: How important are nominal shocks? Carnegie-Rochester Conference Series on Public Policy 41(1).

Farrant, K. and G. Peersman (2006). Is the exchange rate a shock absorber or a source of shocks? New empirical evidence. Journal of Money, Credit and Banking 38(4).

Forni, M. and L. Gambetti (2014). Sufficient information in structural \{VARs\}. Journal of Monetary Economics 66, $124-136$.

Hirata, H., M. A. Kose, C. Otrok, and M. E.Terrones (2012). Global house price fluctuations: Synchronization and determinants. In NBER International Seminar on Macroeconomics 2012. National Bureau of Economic Research, Inc.

Jurado, K., S. Ludvigson, and S. Ng (2013). Measuring uncertainty. mimeo.

Leduc, S. and Z. Liu (2016). Uncertainty shocks are aggregate demand shocks. Journal of Monetary Economics 82.

McCauley, R. N. and P. McGuire (2009). Dollar appreciation in 2008: Safe haven, carry trades, dollar shortage and overhedging. BIS Quarterly Review. 
Mumtaz, H. and K. Theodoridis (2015). The International Transmission Of Volatility Shocks: An Empirical Analysis. Journal of the European Economic Association 13(3).

Mumtaz, H. and K. Theodoridis (2016). The changing transmission of uncertainty shocks in the us: An empirical analysis. Journal of Business 85 Economic Statistics 0(ja), 1-39.

Popp, A. and F. Zhang (2016). The macroeconomic effects of uncertainty shocks: The role of the financial channel. Journal of Economic Dynamics and Control 69, 319 - 349.

Stock, J. H. and M. W. Watson (2012). Disentangling the channels of the 2007-2009 recession. NBER Working Papers 18094, National Bureau of Economic Research, Inc. 
Figure 1: Alternative Measures of Uncertainty

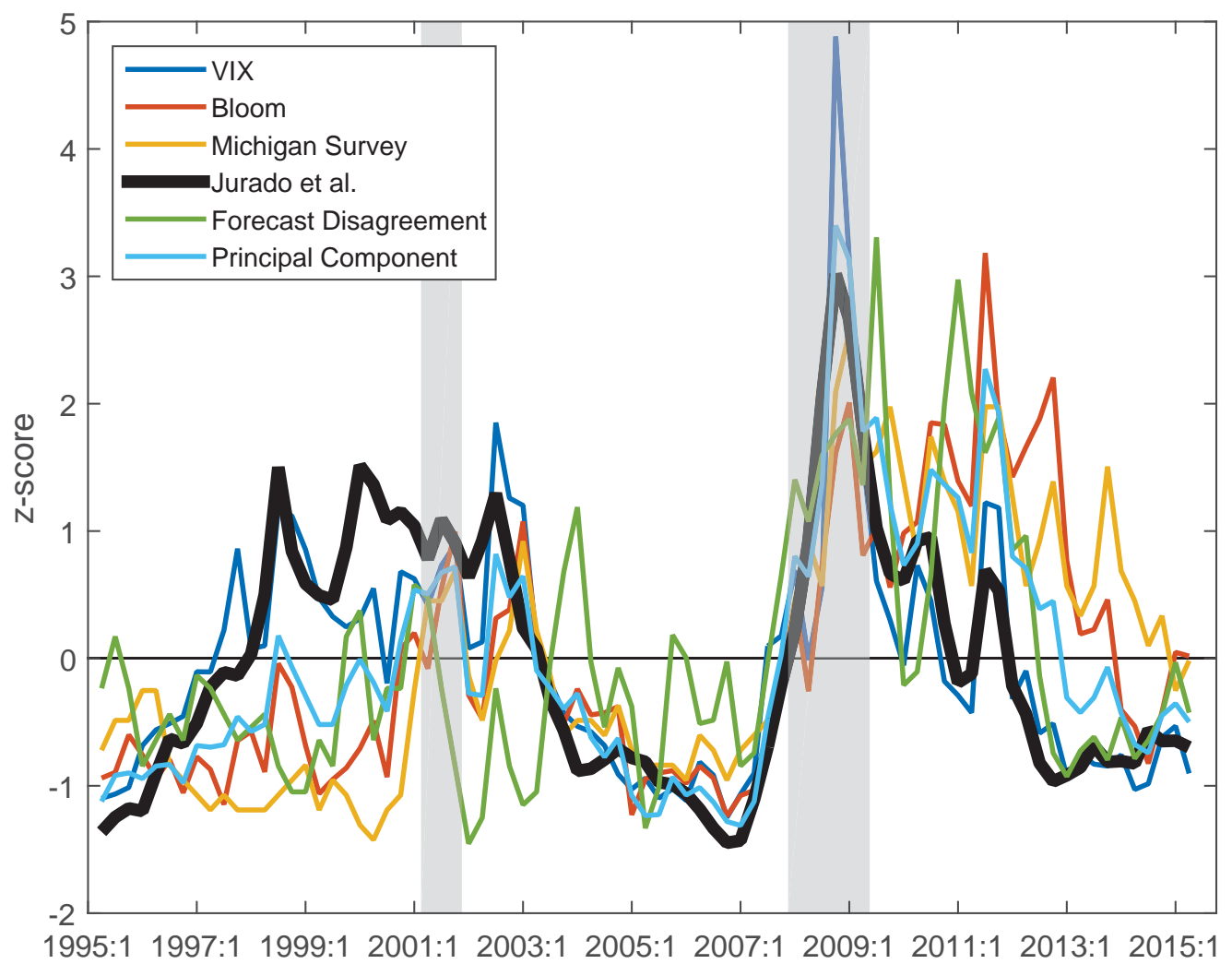

Notes: The shaded vertical bars indicate the NBER-dated recession dates in the United States. Sample: 1995Q2-2015Q2. The VIX: Implied volatility Index, which shows the market's expectation of 30-day volatility in S\&P 500, source: Haver Analytics. Bloom: A measure of consumers' perceived uncertainty, source: http://www.policyuncertainty.com Michigan Survey: Michigan Survey of Expectations, source: University of Michigan. Jurado: An econometric estimate of the volatility of the purely unforecastable component of the future values of a large number of financial variables, source: http://www.sydneyludvigson.com/data-and-appendixes. Forecast disagreement: The variance of the 1-year ahead GDP growth forecasts from the Survey of Professional Forecasters, source: Federal Reserve Bank of Philadelphia. 
Figure 2: Principal Component Estimates of Domestic and Foreign Factors

Figure 3: Responses of Key US Macro Variables to 1 s.d Shock to Uncertainty
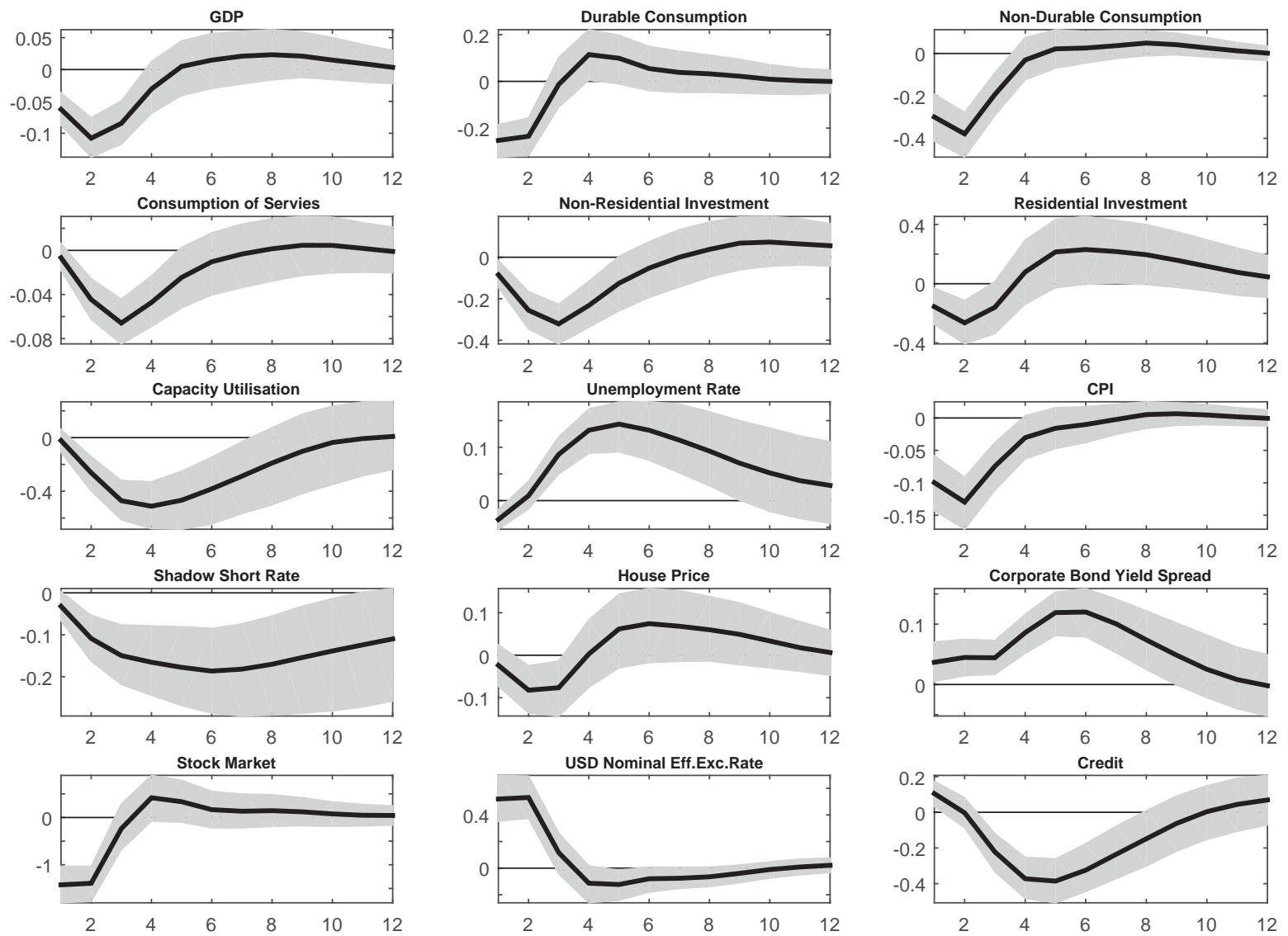

Notes: The solid line represents median responses of the variables to a one- standard-deviation increase in the innovations to uncertainty. The shaded area represents the 68 per cent confidence bands of the estimated median impulse responses. 
Figure 4: Responses Across the World to Uncertainty Shock
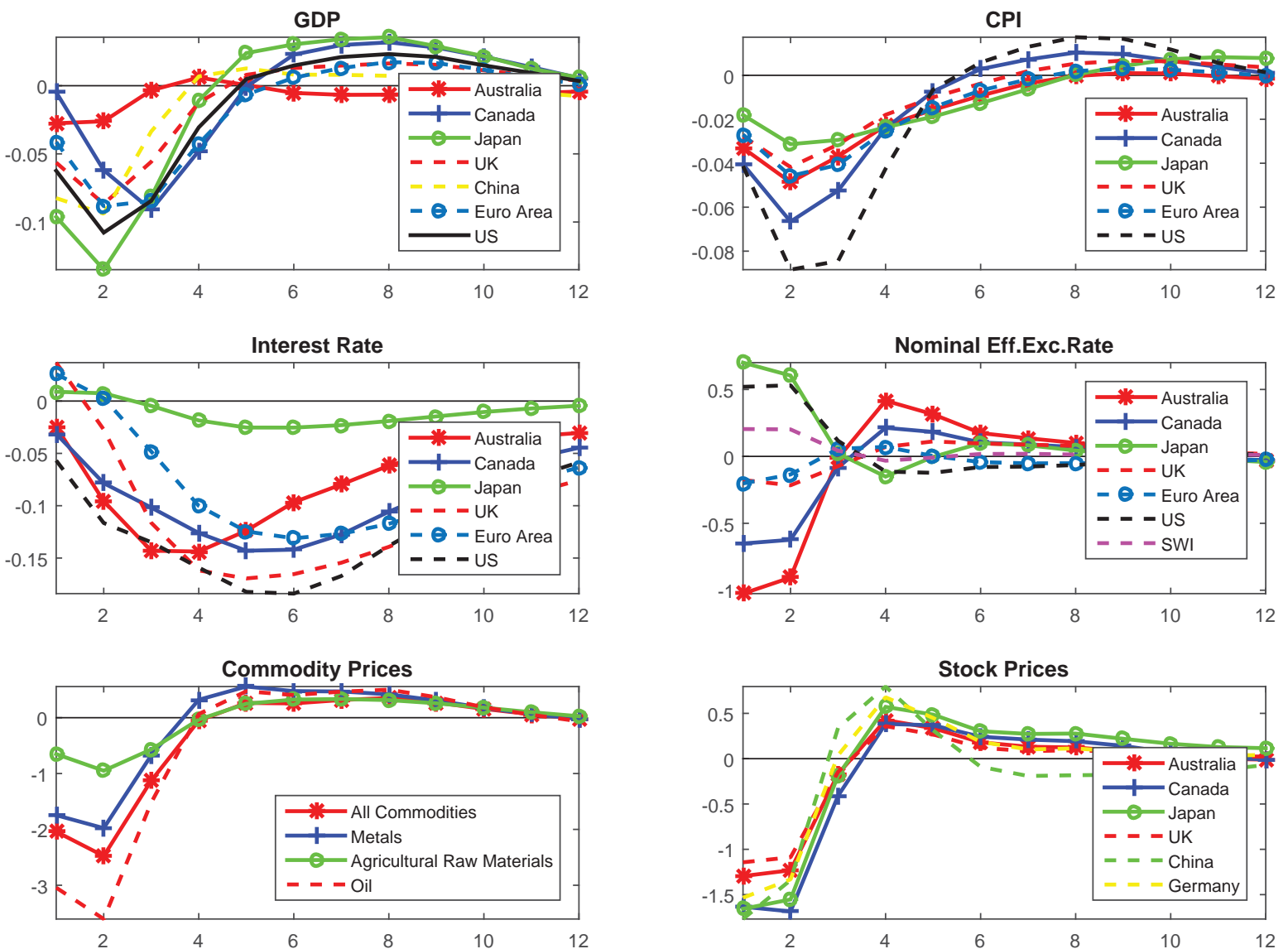

Notes: The lines represents median responses of the variables to a one- standard-deviation increase in the innovations to uncertainty. 
Figure 5: Responses of New Zealand Variables to 1 s.d shock to Uncertainty
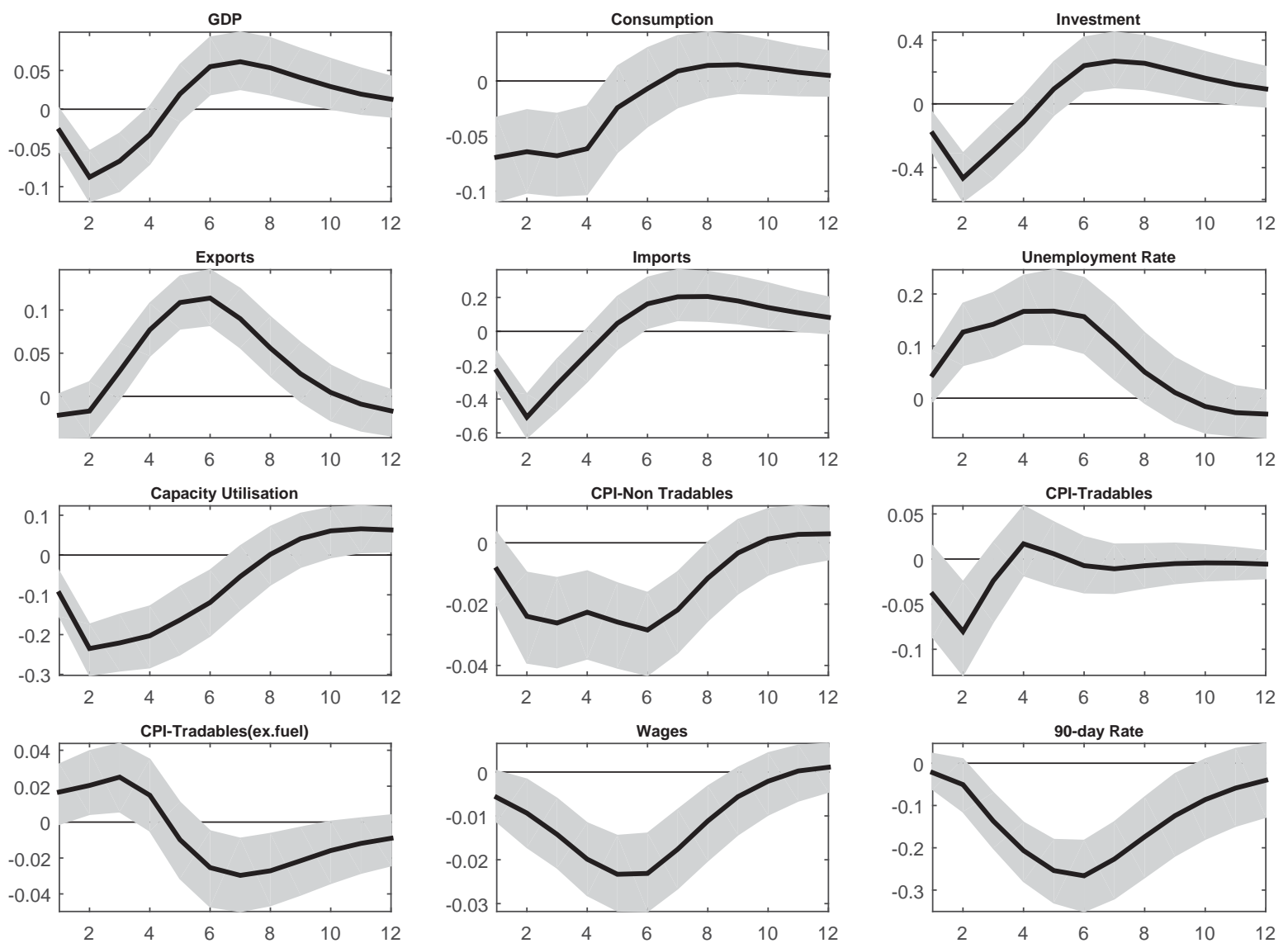

Notes: The solid line represents median responses of the variables to a one- standard-deviation increase in the innovations to uncertainty. The shaded area represents the 68 per cent confidence bands of the estimated median impulse responses. 
Figure 6: Exchange Rates
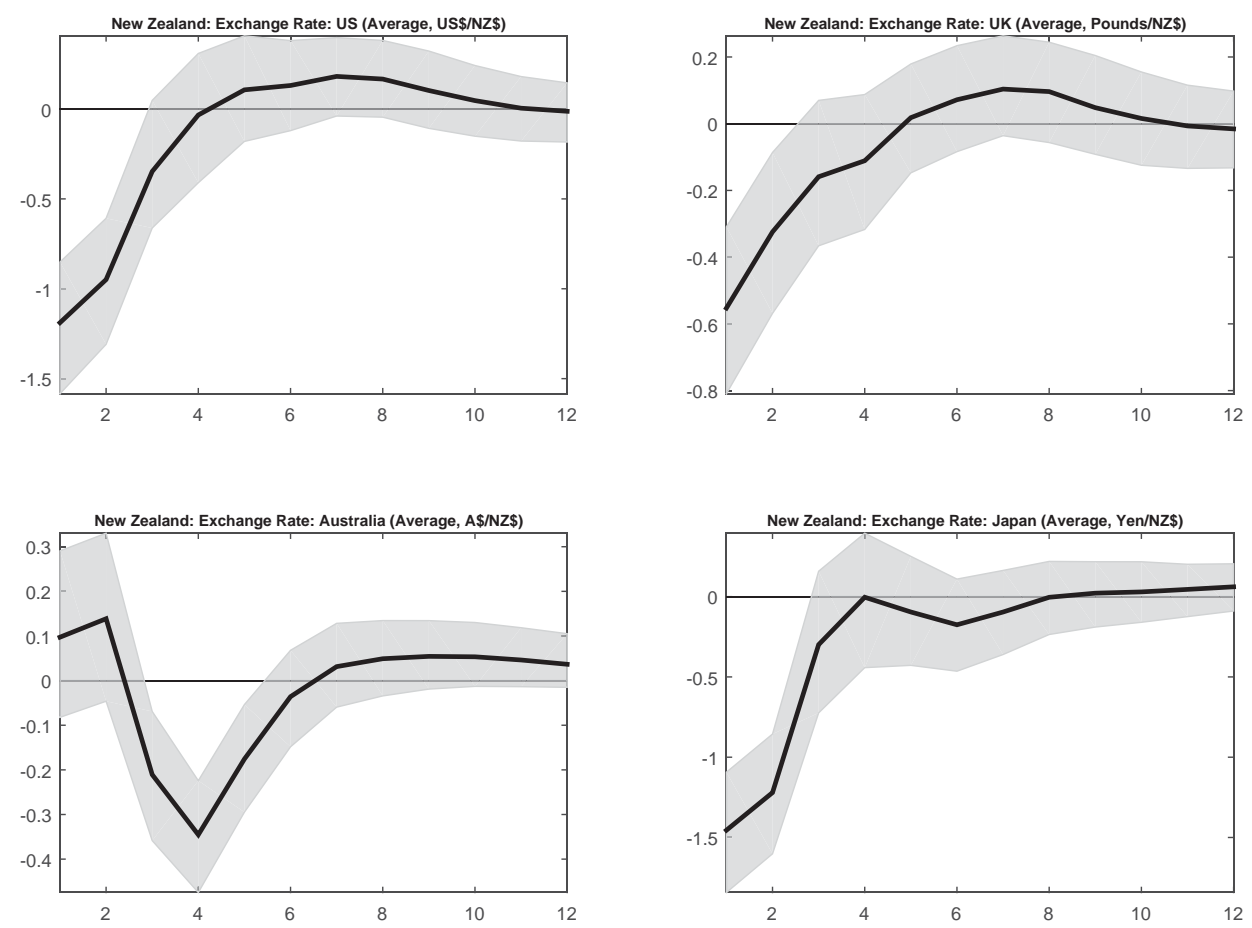

Notes: The solid line represents median responses of the variables to a one- standarddeviation increase in the innovations to uncertainty. The shaded area represents the 68 per cent confidence bands of the estimated median impulse responses. 
Figure 7: Responses of Selected NZ Macro Variables to 1 s.d shock to Uncertainty
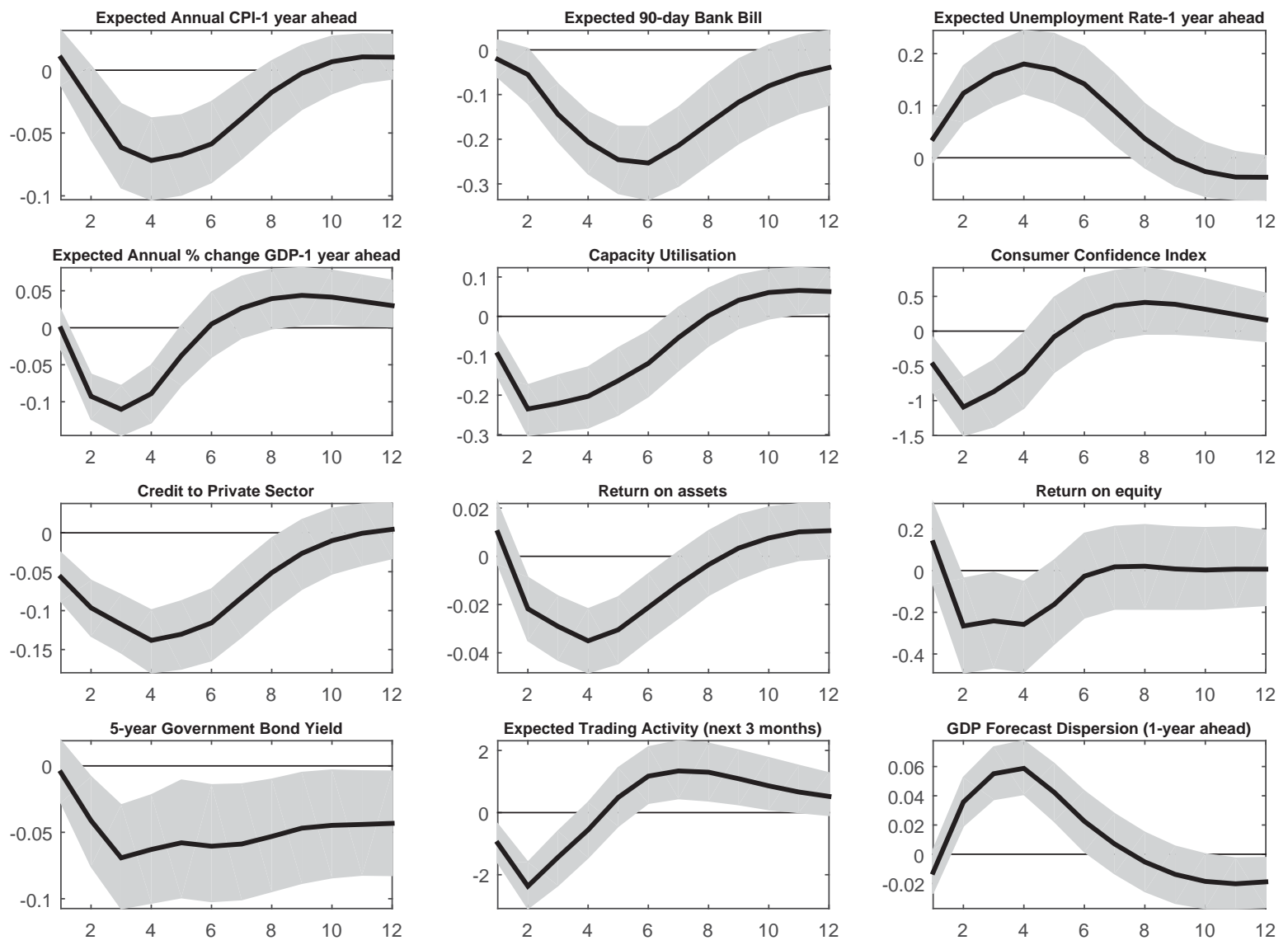

Notes: The solid line represents median responses of the variables to a one- standard-deviation increase in the innovations to uncertainty. The shaded area represents the 68 per cent confidence bands of the estimated median impulse responses. 
Figure 8: Responses of US Variables to Alternative Uncertainty Measures
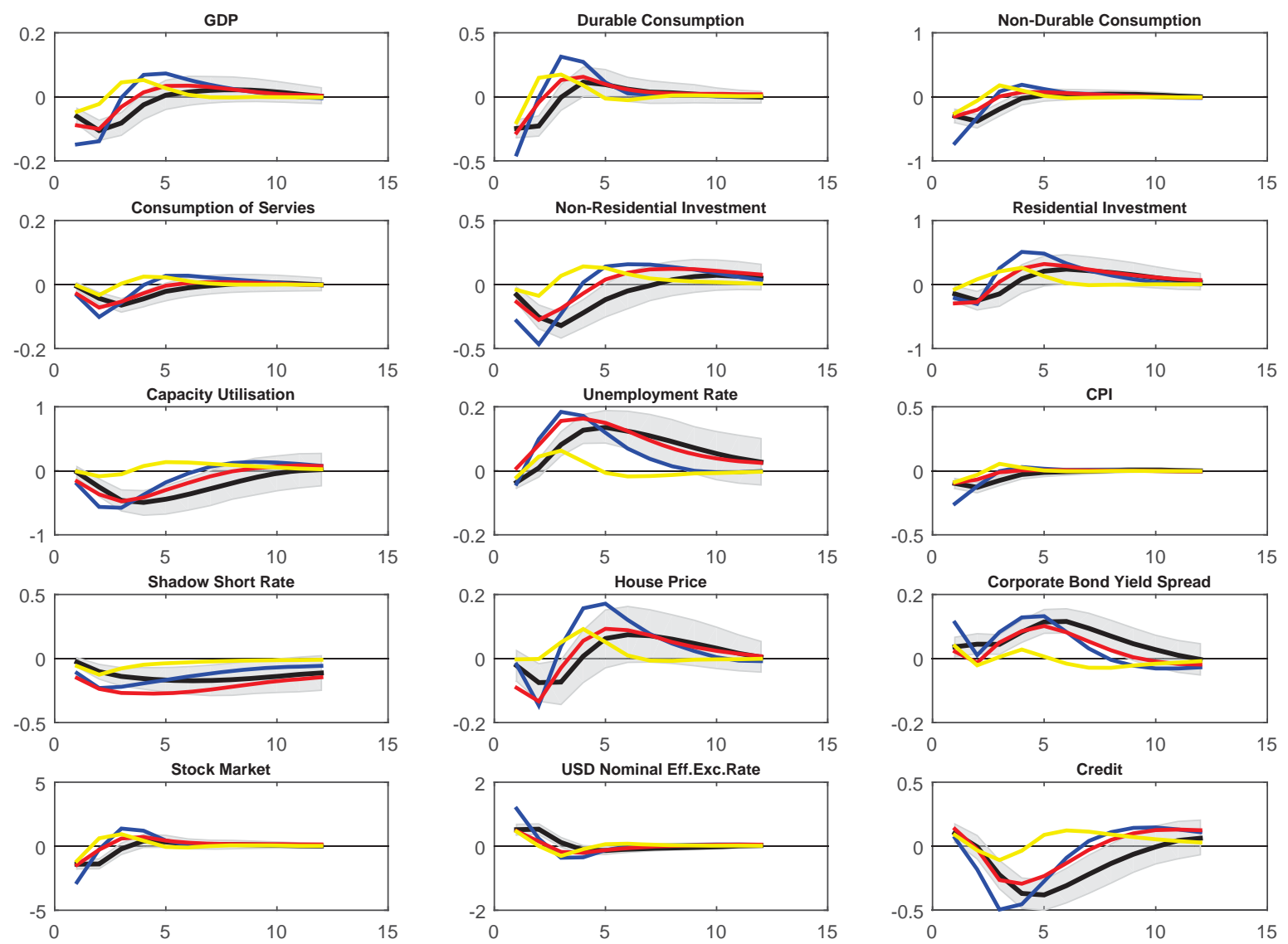

Error Band (Jurado)

Jurado $\longrightarrow$ VIX $\longrightarrow$ Proxy $\quad$ PC

Notes: The solid lines represent the median responses of the variables to a one-standard-deviation increase in the innovations to uncertainty using the baseline index, Bloom's measure, VIX and the principal component measures of uncertainty. The grey shaded area represents the 68 per cent confidence bands of the estimated median impulse responses obtained from the baseline FAVAR. 
Figure 9: Responses of NZ Variables to Alternative Uncertainty Measures
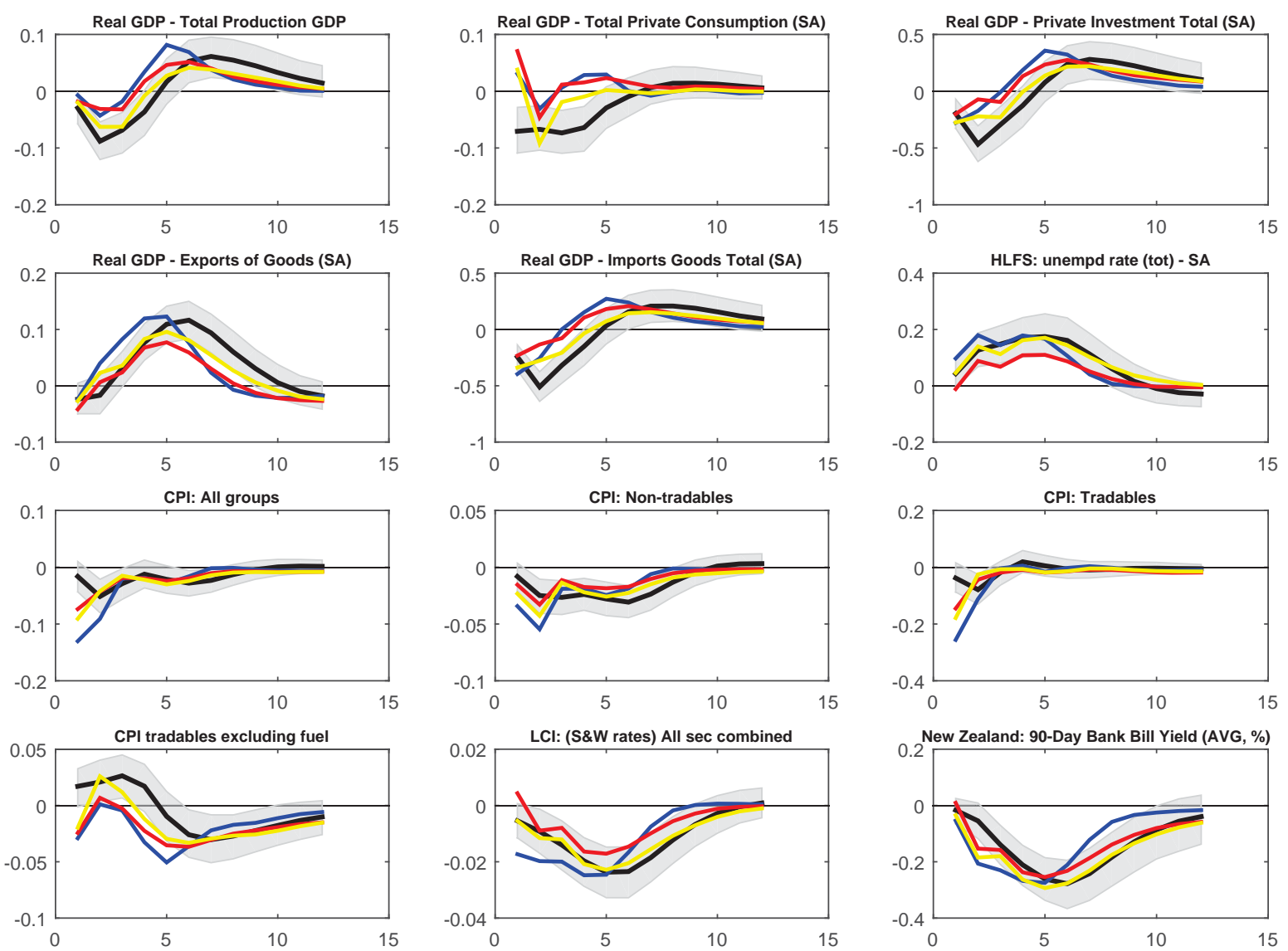

New Zealand: 90-Day Bank Bill Yield (AVG, \%)

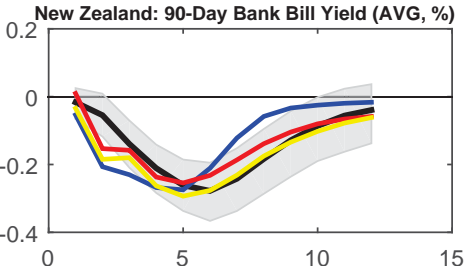

Error Band (Jurado)

Bloom $=\mathrm{PC}$

Notes: The black, yellow, red and blue solid lines represent the median responses of the variables to a onestandard-deviation increase in the innovations to uncertainty using the baseline index, Bloom's measure, VIX and the principal component measures of uncertainty. The grey shaded area represents the 68 per cent confidence bands of the estimated median impulse responses obtained from the baseline FAVAR. 
Figure 10: Dynamic Responses of Key Variables (Simple VAR vs. FAVAR)


Notes: The solid black line represents median responses of the variables to a one-standard-deviation increase in the innovations to uncertainty in simple VAR. The light and dark grey shaded area represents the 68 and 84 per cent confidence bands of the estimated median impulse responses. The red solid line represents median responses of the variables to a one-standard-deviation increase in the innovations to uncertainty in FAVAR. The dashed red lines represent the 68 per cent confidence bands of the estimated median impulse responses 
Table 1: Explanatory Power of Factors for Selected Variables

Foreign Variables

$\mathrm{R}$ squared

Australia: Gross Domestic Product (SA, Mil.Chn.Q3:12-Q2:13.A\$)

$12 \%$

Canada: Gross Domestic Product (SA, Mil.Chn.2007.C\$)

$64 \%$

Japan: Gross Domestic Product (SA, Bil.Chn.2005.Yen)

$29 \%$

UK: Gross Domestic Product (SA, Mil.Chained.2011.Pounds)

$58 \%$

US: Gross Domestic Product (SAAR, Bil.\$)

$66 \%$

China: Gross Domestic Product (SA, Bil.2010.Yuan)

$27 \%$

Euro Area: GDP

$71 \%$

World: Commodity Price Index: All Commodities $(2010=100)$

$88 \%$

World: Non-fuel Primary Commodities Index $(2010=100)$

$69 \%$

World: Commodity Price Index: Metals $(2010=100)$

$65 \%$

World: Commodity Price Index: Agricultural Raw Materials $(2010=100)$

$53 \%$

World: Commodity Price Index: Food \& Beverage (2005=100)

$46 \%$

Dubai Oil Price

$69 \%$

Australia: Nominal Effective Exchange Rate $(2010=100)$

$75 \%$

$16 \%$

Euro Area: Nominal Effective Exchange Rate (Avg, NSA,2010=100)

$34 \%$

United Kingdom: Nominal Effective Exchange Rate (Avg, NSA,2010=100)

$43 \%$

United States: Nominal Effective Exchange Rate (Avg, NSA,2010=100)

$63 \%$

China, PR: Nominal Effective Exchange Rate $(2010=100)$

$43 \%$

Australia, Consumer Price Index, SA

$28 \%$

Canada: Consumer Price Index (SA, 2002=100)

EA 11-18: Monetary Union: Index of Consumer Prices(SA/H, 2005=100)

$48 \%$

$63 \%$

Japan: Consumer Price Index $(\mathrm{SA} / \mathrm{H}, 2010=100)$

$20 \%$

U.K.: Harmonized Index of Consumer Prices [HICP] (SA, 2005=100)

$44 \%$

$82 \%$

$83 \%$

Australia: Official Cash Rate (EOP, \%)

$90 \%$

Canada: Overnight Money Market Financing Rate [Target] (EOP, \%)

$94 \%$

U.K.: Bank of England Official Bank Rate (EOP, \%)

$42 \%$

Japan: Call Rate: Uncollateralized 3-Month (EOP, \%)

$95 \%$

Domestic Variables

$58 \%$

Real GDP - Total Production GDP

$58 \%$

CPI: All groups

$61 \%$

CPI: Non-tradables

$37 \%$

CPI: Tradables

$63 \%$

HLFS: unempd rate (tot) - SA

$76 \%$

$78 \%$

$87 \%$

New Zealand: 90-Day Bank Bill Yield (AVG, \%)

$76 \%$

Export Price Index -All Merchandise

$78 \%$

$69 \%$

QSBO: Ecnmy wide - Gen bus sit: SA, net

$33 \%$ 
Table 2: Data

\begin{tabular}{|c|c|c|}
\hline Index & Transformation & Description \\
\hline Domestic & Block & \\
\hline 1 & 2 & Real GDP - Total Household Consumption (SA) \\
\hline 2 & 2 & Real GDP - Total Private Consumption (SA) \\
\hline 3 & 2 & Real GDP - Total Govt Consumption (SA) \\
\hline 4 & 2 & Real GDP - Private Investment Total (SA) \\
\hline 5 & 2 & Real GDP - Govt Investment Total (SA) \\
\hline 6 & 2 & Real GDP - Total Investment (SA) \\
\hline 7 & 2 & Real GDP - Imports Goods Total (SA) \\
\hline 8 & 2 & Real GDP - Imports Services (SA) \\
\hline 9 & 2 & Real GDP - Imports Total (SA) \\
\hline 10 & 2 & Real GDP - Exports of Goods (SA) \\
\hline 11 & 2 & Real GDP - Exports of Services (SA) \\
\hline 12 & 2 & Real GDP - Exports Total (SA) \\
\hline 13 & 2 & Real GDP - Gross National Expenditure (SA) \\
\hline 14 & 2 & $\begin{array}{l}\text { Real Prod GDP - Manufacturing - Total (SA) (HOTP, prior to 87q2: RBNZ } \\
\text { backdate) }\end{array}$ \\
\hline 15 & 2 & Real GDP - Total Production GDP \\
\hline 16 & 2 & Real GDP - Private Investment Dwellings (SA) - WARNING rough RB \\
\hline 17 & 2 & QMS - Sales: Total exc meat and dairy (qtly real SA) \\
\hline 18 & 2 & HLFS: emp (tot) - SA \\
\hline 19 & 2 & HLFS: unemp (tot) - SA \\
\hline 20 & 2 & HLFS: Tot no of act hrs wrkd each wk - (SA) \\
\hline 21 & 2 & HLFS: Tot lab force - SA \\
\hline 22 & 2 & HLFS: not in lab force (tot) - SA \\
\hline 23 & 0 & HLFS: Lab force partcption rate (tot) - SA \\
\hline 24 & 0 & HLFS: unempd rate (tot) - SA \\
\hline 25 & 2 & QES: Tot gross earnings: Tot All Ind - SA \\
\hline 26 & 2 & QES: Tot paid hrs: Tot All Ind - SA \\
\hline 27 & 3 & LCI: (S\&W rates) All sec combined \\
\hline 28 & 2 & perm \& long-term migration - arrivals s.a. \\
\hline 29 & 2 & perm \& long-term migration - departures s.a. \\
\hline 30 & 2 & HLFS: Wrkng age pop (tot)- SA \\
\hline 31 & 3 & Housing value \% HHold disposable income \\
\hline 32 & 3 & Currency \\
\hline 33 & 2 & Notes \& coin held by the public (sa) \\
\hline 34 & 2 & M1 (sa) \\
\hline 35 & 3 & M2 \\
\hline 36 & 3 & M3 \\
\hline 37 & 3 & PSC \\
\hline 38 & 3 & PSCR \\
\hline 39 & 2 & QUARTERLY HOUSE PRICE INDEX -QUOTABLE VALUE- s.a. \\
\hline 40 & 2 & HPI: Total NZ (for houses, flats, home and income) (sa) \\
\hline 41 & 3 & PPII - Agriculture \\
\hline 42 & 3 & PPIO - Agriculture \\
\hline 43 & 3 & PPII - Manufacturing \\
\hline 44 & 3 & PPIO - Manufacturing \\
\hline 45 & 3 & PPII - Wholesale Trade \\
\hline 46 & 3 & PPIO - Wholesale Trade \\
\hline 47 & 3 & PPII - Retail Trade \\
\hline 48 & 3 & PPIO - Retail Trade \\
\hline 49 & 3 & PPII - All Industries \\
\hline 50 & 3 & PPIO - All Industries \\
\hline 51 & 3 & CPI: Goods component \\
\hline 52 & 3 & CPI: Serv. component \\
\hline 53 & 3 & CPI: All groups \\
\hline 54 & 3 & CPI: All groups less Food (group) \\
\hline 55 & 3 & CPI: Non-tradables \\
\hline 56 & 3 & CPI: Tradables \\
\hline
\end{tabular}


Table 2: Data

\begin{tabular}{|c|c|c|}
\hline Index & Transformation & Description \\
\hline 57 & 3 & CPI tradables excluding fuel \\
\hline 58 & 3 & Import price index - Petroleum and Petroleum Products \\
\hline 59 & 3 & Import price index - Total Non-Commodity Manufactured Goods \\
\hline 60 & 3 & Import Price Index - Total Non-Oil Commodity Goods \\
\hline 61 & 3 & Import Price Index Total Merchandise Imports \\
\hline 62 & 3 & Import Price Index Capital Goods - Total \\
\hline 63 & 3 & Export price index - Dairy Products (Agricultural) \\
\hline 64 & 3 & Export price index - Meat (Food and Beverages) \\
\hline 65 & 3 & Export price index of Total Manufactures \\
\hline 66 & 3 & Export Price Index -All Merchandise \\
\hline 67 & 2 & Value of Total Merchandise Exports (excludes re-exports) - s.a. \\
\hline 68 & 2 & OTI Value of Total Merchandise Imports - s.a. \\
\hline 69 & 0 & QSBO: Ecnmy wide - Gen bus sit: SA, net \\
\hline 70 & 0 & QSBO: Ecnmy wide - Domestic trading activity - past 3 mths, SA \\
\hline 71 & 0 & QSBO: Ecnmy wide - Domestic trading activity - nxt 3 mths, SA \\
\hline 72 & 0 & RBNZ survey of exp (business) - Exp Ann CPI - 1 year from now \\
\hline 73 & 0 & RBNZ survey of exp (business) - Exp Ann CPI - 2 years from now \\
\hline 74 & 0 & RBNZ survey of exp (business) - Exp 90-day Bank Bill - End current qtr \\
\hline 75 & 0 & RBNZ survey of exp (business) - Exp 90-day Bank Bill - 3qtrs from now \\
\hline 76 & 0 & $\begin{array}{l}\text { RBNZ survey of exp (business) - Exp HLFS Unemployment Rate - } 1 \text { year } \\
\text { ahead }\end{array}$ \\
\hline 77 & 0 & $\begin{array}{l}\text { RBNZ survey of exp (business) - Exp HLFS Unemployment Rate - } 2 \text { years } \\
\text { ahead }\end{array}$ \\
\hline 78 & 0 & RBNZ survey of exp (business) - Exp Quarterly CPI - End cur qtr \\
\hline 79 & 0 & RBNZ survey of exp (business) - Exp Qtr CPI - next qtr \\
\hline 80 & 0 & RBNZ survey of exp (business) - Exp Qtr (S.A.) GDP - Previous quarter \\
\hline 81 & 0 & $\begin{array}{l}\text { RBNZ survey of exp (business) - Expected Quarterly (S.A.) GDP - Current } \\
\text { quarter }\end{array}$ \\
\hline 82 & 0 & $\begin{array}{l}\text { RBNZ survey of exp (business) - Expected Annual \% change GDP - } 1 \text { year } \\
\text { ahead }\end{array}$ \\
\hline 83 & 0 & $\begin{array}{l}\text { RBNZ survey of exp (business) - Expected Annual \% change GDP - } 2 \text { years } \\
\text { ahead }\end{array}$ \\
\hline 84 & 0 & QSBO - ECONOMY-WIDE - Gen. bus. situation - Seasonally Adjusted \\
\hline 85 & 0 & QSBO - ECONOMY-WIDE - Capacity Utilisation \\
\hline 86 & 0 & QSBO - ECONOMY-WIDE - Exporters Capacity Utilisation \\
\hline 87 & 0 & QSBO - ECONOMY-WIDE - PAST 3 MONTHS - No.s emp \\
\hline 88 & 0 & $\begin{array}{l}\text { QSBO - ECONOMY-WIDE - NEXT } 3 \text { MONTHS - Domestic Trading Ac- } \\
\text { tivity (s.a.) }\end{array}$ \\
\hline 89 & 0 & $\begin{array}{l}\text { QSBO - ECONOMY-WIDE - PAST } 3 \text { MONTHS - Domestic Trading Ac- } \\
\text { tivity (s.a.) }\end{array}$ \\
\hline 90 & 0 & WESTPAC-McDERMOT-MILLER - Consumer Confidence Index \\
\hline 91 & 0 & $\begin{array}{l}\text { MARKETSCOPE/UMR SURVEY OF EXP OF INFLATION - Current } \\
\text { Inflation }\end{array}$ \\
\hline 92 & 0 & $\begin{array}{l}\text { MARKETSCOPE/UMR SURVEY OF EXP OF INFLATION - Net \% Exp } \\
\text { Higher Inflation (12 Mths) }\end{array}$ \\
\hline 93 & 0 & $\begin{array}{l}\text { MARKETSCOPE/UMR SURVEY OF EXP OF INFLATION - Exp Infla- } \\
\text { tion (12 Months) - Median }\end{array}$ \\
\hline 94 & 3 & Total Dwellings - New - value (quarterly total) \\
\hline 95 & 2 & BUILDING WORK PUT IN PLACE - DWELLINGS - TOTAL - SA \\
\hline 96 & 2 & $\begin{array}{l}\text { REAL BUILDING WORK PUT IN PLACE - RESIDENTIAL - S.A. (new } \\
\text { method) }\end{array}$ \\
\hline 97 & 2 & $\begin{array}{l}\text { REAL BUILDING WORK PUT IN PLACE - NON-RESIDENTIAL - S.A. } \\
\text { (new method) }\end{array}$ \\
\hline 98 & 2 & $\begin{array}{l}\text { REAL BUILDING WORK PUT IN PLACE - ALL BUILDINGS - S.A. } \\
\text { (new method) }\end{array}$ \\
\hline 99 & 2 & New Zealand: Nominal Effective Exchange Rate $(2010=100)$ \\
\hline 100 & 2 & New Zealand: Real Eff Exchange Rate: Consumer Price Basis $(2010=100)$ \\
\hline 101 & 2 & New Zealand: Exchange Rate: US (Average, US\$/NZ\$) \\
\hline
\end{tabular}


Table 2: Data

\begin{tabular}{|c|c|c|}
\hline Index & Transformation & Description \\
\hline 102 & 2 & New Zealand: Exchange Rate: UK (Average, Pounds/NZ\$) \\
\hline 103 & 2 & New Zealand: Exchange Rate: Australia (Average, $\mathrm{A} \$ / \mathrm{NZ} \$$ ) \\
\hline 104 & 2 & New Zealand: Exchange Rate: Japan (Average, Yen/NZ\$) \\
\hline 105 & 2 & New Zealand: Trade-Weighted Exchange Rate Index (Oct-31-14=76.44) \\
\hline 106 & 0 & New Zealand: 90-Day Bank Bill Yield (AVG, \%) \\
\hline 107 & 0 & New Zealand: 5-Year Government Bond Yield (\%) \\
\hline 108 & 0 & New Zealand: 10-Year Government Bond Yield (AVG, \%) \\
\hline 109 & 2 & New Zealand: Terms of Trade $(S A, 2005=100)$ \\
\hline 110 & 2 & New Zealand: Capital Index: NZSX All Indexes (EOP, Jun-30-86=1000) \\
\hline 111 & 2 & New Zealand: Gross Index: NZSX All Indexes (EOP, Jun-30-86=1000) \\
\hline 112 & 2 & $\begin{array}{l}\text { New Zealand: Industrial Production excl Construction (SA, Q3.09- } \\
\text { Q2.10=100) }\end{array}$ \\
\hline 113 & 0 & Return on assets \\
\hline 114 & 0 & Return on equity \\
\hline 115 & 0 & NZ GDP Forecast Uncertainty \\
\hline \multicolumn{3}{|c|}{ Foreign Block } \\
\hline 1 & 2 & Australia: Nominal Effective Exchange Rate $(2010=100)$ \\
\hline 2 & 2 & Australia: Real Eff Exch Rate: Based on Consumer Prices $(2010=100)$ \\
\hline 3 & 2 & Euro Area: Nominal Effective Exchange Rate (Avg, NSA,2010=100) \\
\hline 4 & 2 & Euro Area: Real Effective Exchange Rate based on rel. CPI $(2010=100)$ \\
\hline 5 & 2 & Japan: Nominal Effective Exchange Rate (Avg, NSA,2010=100) \\
\hline 6 & 2 & Japan: Real Effective Exchange Rate: Consumer Price basis $(2010=100)$ \\
\hline 7 & 2 & United Kingdom: Nominal Effective Exchange Rate (Avg, NSA,2010=100) \\
\hline 8 & 2 & U.K.: Real Effective Exch Rate: Consumer Price basis $(2010=100)$ \\
\hline 9 & 2 & United States: Nominal Effective Exchange Rate (Avg, NSA,2010=100) \\
\hline 10 & 2 & US: Real Effective Exch Rate: Consumer Price basis $(2010=100)$ \\
\hline 11 & 2 & China, PR: Nominal Effective Exchange Rate $(2010=100)$ \\
\hline 12 & 2 & China, PR: Real Effective Exch Rate: Consumer Price basis $(2010=100)$ \\
\hline 13 & 2 & Canada: Nominal Effective Exchange Rate (Avg, NSA,2010=100) \\
\hline 14 & 2 & Canada: Real Effective Exchange Rate: Consumer Price Basis $(2010=100)$ \\
\hline 15 & 2 & Switzerland: JP Morgan Broad Nominal Effective Exchange Rate \\
\hline 16 & 0 & Australia: Official Cash Rate (EOP, \%) \\
\hline 17 & 0 & Canada: Overnight Money Market Financing Rate [Target] (EOP, \%) \\
\hline 18 & 0 & U.K.: Bank of England Official Bank Rate (EOP, \%) \\
\hline 19 & 0 & Australia: 3-Month Bank Accepted Bills (AVG, \%) \\
\hline 20 & 0 & $\begin{array}{l}\text { U.K.: 3-Month London Interbank Offered Rate: Based on British Pound } \\
\text { (AVG, \%) }\end{array}$ \\
\hline 21 & 0 & Japan: Call Rate: Uncollateralized 3-Month (EOP, \%) \\
\hline 22 & 0 & $\begin{array}{l}\text { U.K.: 3-Month London Interbank Offered Rate: Based on British Pound } \\
\text { (EOP, \%) }\end{array}$ \\
\hline 23 & 0 & EA 11-19: 3-Month Average Money Market Rate \\
\hline 24 & 0 & Australia: 5-Year Treasury Bond Yield (EOP, \%) \\
\hline 25 & 0 & Australia: 10-Year Treasury Bond Yield (AVG, \%) \\
\hline 26 & 0 & Canada: 1-Year Treasury Bill Yield [Last Wednesday] (EOP, \%) \\
\hline 27 & 0 & Canada: 5-Year Benchmark Bond Yield [Last Wednesday] (EOP, \%) \\
\hline 28 & 0 & Canada: 10-Year Benchmark Bond Yield (AVG, \%) \\
\hline 29 & 0 & EA 11-18: 5-Year Benchmark Government Bond Yield (AVG, \%) \\
\hline 30 & 0 & EA 11-18: 10-Year Benchmark Government Bond Yield (AVG, \%) \\
\hline 31 & 0 & Japan: 1-Year Benchmark Government Bond Yield (AVG, \% p.a.) \\
\hline 32 & 0 & Japan: 5-Year Benchmark Government Bond Yield (AVG, \% p.a.) \\
\hline 33 & 0 & Japan: 10-Year Benchmark Government Bond Yield (AVG, \% p.a.) \\
\hline 34 & 0 & U.K.: 1-Year London Interbank Offered Rate: Based on British Pound (\%) \\
\hline 35 & 0 & U.K.: Government Bonds, 5-Year Nominal Par Yield (AVG, \%) \\
\hline 36 & 0 & U.K.: Government Bonds, 10-Year Nominal Par Yield (AVG, \%) \\
\hline 37 & 2 & Australia: Gross Domestic Product (SA, Mil.Chn.Q3:12-Q2:13.A $\$$ ) \\
\hline 38 & 2 & Canada: Gross Domestic Product (SA, Mil.Chn.2007.C\$) \\
\hline 39 & 2 & Japan: Gross Domestic Product (SA, Bil.Chn.2005.Yen) \\
\hline 40 & 2 & U.K.: Gross Domestic Product (SA, Mil.Chained.2011.Pounds) \\
\hline
\end{tabular}


Table 2: Data

\begin{tabular}{|c|c|c|}
\hline Index & Transformation & Description \\
\hline 41 & 2 & China: Gross Domestic Product (SA, Bil.2010.Yuan) \\
\hline 42 & 2 & EURO Area GDP \\
\hline 43 & 2 & Australia, CPI, SA \\
\hline 44 & 2 & Canada: Consumer Price Index (SA, 2002=100) \\
\hline 45 & 2 & EA 11-18: Monetary Union: Index of Consumer Prices(SA/H, 2005=100) \\
\hline 46 & 2 & Japan: Consumer Price Index (SA/H, 2010=100) \\
\hline 47 & 2 & U.K.: Harmonized Index of Consumer Prices [HICP] $(\mathrm{SA}, 2005=100)$ \\
\hline 48 & 2 & Canada: Industrial Price Index: All Commodities (SA, 2010=100) \\
\hline 49 & 2 & EA 18: PPI: Industry excluding Construction $(\mathrm{SA}, 2010=100)$ \\
\hline 50 & 2 & Japan: Output Price: Manufacturing (SA, 2005=100) \\
\hline 51 & 2 & U.K.: PPI: Net Output Prices: Manufactured Products (SA, 2010=100) \\
\hline 52 & 2 & Australia: Terms of Trade $(\mathrm{SA}, 2005=100)$ \\
\hline 53 & 2 & Japan: Terms of Trade $(\mathrm{SA}, 2010=100)$ \\
\hline 54 & 2 & US: Terms of Trade $(\mathrm{SA}, 2005=100)$ \\
\hline 55 & 2 & Australia: Import Price Index (SA, Q3.2011-Q2.2012=100) \\
\hline 56 & 2 & Japan: Import Price Index: All Commodities (SA, 2010=100) \\
\hline 57 & 2 & U.K.: Import Price Index: Total Goods (SA, 2011=100) \\
\hline 58 & 2 & Australia: Export Price Index (SA, Q3.2011-Q2.2012=100) \\
\hline 59 & 2 & Japan: Export Price Index: All Commodities (SA, 2010=100) \\
\hline 60 & 2 & $\begin{array}{l}\text { Australia: Industrial Production excl Construction } \quad \text { (SA, Q3:12- } \\
\text { Q2:13=100) }\end{array}$ \\
\hline 61 & 2 & $\begin{array}{l}\text { Canada: Industrial Production: Manufacturing, Mining \& Utilities (SA, } \\
2007=100)\end{array}$ \\
\hline 62 & 2 & EA 18: IP: Industry excluding Construction (SA/WDA, 2010=100) \\
\hline 63 & 2 & U.K.: Industrial Production excluding Construction (SA, 2011=100) \\
\hline 64 & 0 & Australia: Unemployment Rate (SA, \%) \\
\hline 65 & 0 & Canada: Unemployment Rate: 15 Years and Over (SA, \%) \\
\hline 66 & 0 & Japan: Unemployment Rate (SA, \%) \\
\hline 67 & 0 & $\begin{array}{l}\text { U.K.: Unemployment Rate: Aged } 16 \text { and Over [3-Mo Moving Avg](SA, } \\
\%)\end{array}$ \\
\hline 68 & 0 & Australia: NAB Business Survey: Capacity Utilization (NSA, \%) \\
\hline 69 & 0 & Japan: Operating Rate: Manufacturing (NSA, 2010=100) \\
\hline 70 & 0 & Australia: NAB Business Survey: Capacity Utilization (SA, \%) \\
\hline 71 & 0 & Canada: Capacity Utilization: Total Industrial (SA, \%) \\
\hline 72 & 0 & EA 17: Capacity Utilization: Manufacturing (SA, \%) \\
\hline 73 & 0 & Japan: Operating Rate: Manufacturing (SA, 2010=100) \\
\hline 74 & 2 & Australia: Imports of Goods, cif (SA, Mil.A $\$)$ \\
\hline 75 & 2 & Canada: Imports of Goods, BOP Basis (SA, Mil C\$) \\
\hline 76 & 2 & Japan: Imports of Goods (SA, Bil.Yen) \\
\hline 77 & 2 & U.K.: Imports of Goods (SA, Mil.Pounds) \\
\hline 78 & 2 & Australia: Exports of Goods, fob (SA, Mil.A $\$$ ) \\
\hline 79 & 2 & Canada: Exports of Goods, BOP Basis (SA, Mil.C\$) \\
\hline 80 & 2 & Japan: Exports of Goods (SA, Bil.Yen) \\
\hline 81 & 2 & U.K.: Exports of Goods (SA, Mil.Pounds) \\
\hline 82 & 2 & $\begin{array}{l}\text { World Bank Commodity Price Index for Emerging Countries: NonEnergy } \\
(2010=100)\end{array}$ \\
\hline 83 & 2 & $\begin{array}{l}\text { World Bank Commodity Price Index for Emerging Countries: Agriculture } \\
(2010=100)\end{array}$ \\
\hline 84 & 2 & $\begin{array}{l}\text { WB Commodity Price Index for Emerging Countries: Metals \& Minerals } \\
(2010=100)\end{array}$ \\
\hline 85 & 2 & World: Commodity Price Index: All Commodities $(2010=100)$ \\
\hline 86 & 2 & World: Non-fuel Primary Commodities Index $(2010=100)$ \\
\hline 87 & 2 & World: Commodity Price Index: Metals $(2010=100)$ \\
\hline 88 & 2 & World: Commodity Price Index: Agricultural Raw Materials $(2010=100)$ \\
\hline 89 & 2 & World: Commodity Price Index: Food \& Beverage $(2005=100)$ \\
\hline 90 & 2 & Dubai Oil Price \\
\hline 91 & 2 & G7 Index: Share Price Index (US\$ Dec-31-76=100) \\
\hline 92 & 2 & Australia: Stock Price Index: All Ordinaries (AVG, Jan-01-80=500) \\
\hline
\end{tabular}


Table 2: Data

\begin{tabular}{|c|c|c|}
\hline Index & Transformation & Description \\
\hline 93 & 2 & Canada: S\&P/TSX Composite Index, Close Price (AVG, 1975=1000) \\
\hline 94 & 2 & Japan: Nikkei Stock Average: TSE 225 Issues (AVG, May-16-49=100) \\
\hline 95 & 2 & U.K.: London Stock Exchange: FTSE 100 (AVG, Jan-2-84=1000) \\
\hline 96 & 2 & Germany: Capital Market Indexes: DAX 100 (EOP, Dec-30-87=500) \\
\hline 97 & 2 & Shanghai Stock Exc. \\
\hline US & Block & \\
\hline 98 & 2 & Industrial Production Index (SA, 2007=100) \\
\hline 99 & 2 & Industrial Production: Mining $(\mathrm{SA}, 2007=100)$ \\
\hline 100 & 2 & Industrial Production: Electric and Gas Utilities (SA, 2007=100) \\
\hline 101 & 2 & Industrial Production: Nondurable Manufacturing (SA, 2007=100) \\
\hline 102 & 2 & Industrial Production: Durable Goods [NAICS] $($ SA, 2007=100) \\
\hline 103 & 2 & Industrial Production: Manufacturing [NAICS] (SA, 2007=100) \\
\hline 104 & 2 & Industrial Production: Final Products (SA, 2007=100) \\
\hline 105 & 2 & Industrial Production: Consumer Goods (SA, 2007=100) \\
\hline 106 & 2 & Industrial Production: Durable Consumer Goods (SA, 2007=100) \\
\hline 107 & 2 & Industrial Production: Nondurable Consumer Goods (SA, 2007=100) \\
\hline 108 & 2 & Industrial Production: Business Equipment (SA, 2007=100) \\
\hline 109 & 2 & Industrial Production: Materials (SA, 2007=100) \\
\hline 110 & 2 & Industrial Production: Durable Goods Materials (SA, 2007=100) \\
\hline 111 & 2 & Industrial Production: Nondurable Goods Materials (SA, 2007=100) \\
\hline 112 & 2 & Personal Income (SAAR, Bil.\$) \\
\hline 113 & 2 & Personal Current Transfer Receipts (SAAR, Bil.\$) \\
\hline 114 & 2 & US: Industrial Production excluding Construction (SA, 2007=100) \\
\hline 115 & 2 & US: Industrial Production: Manufacturing $(\mathrm{SA}, 2007=100)$ \\
\hline 116 & 2 & US: IP: Intermediate Goods Nonindustrial Supplies (SA, 2007=100) \\
\hline 117 & 2 & $\begin{array}{l}\text { US: Industrial Production: Capital Goods Business Equipment (SA, } \\
2007=100)\end{array}$ \\
\hline 118 & 0 & US: Capacity Utilization: Manufacturing (SA, \%) \\
\hline 119 & 0 & US: Conference Board: Consumer Confidence $(\mathrm{SA}, 1985=100)$ \\
\hline 120 & 2 & US: Total Employees on Nonfarm Payrolls (SA, Thous) \\
\hline 121 & 2 & US: All Employees: Goods-Producing Industries (SA, Thous) \\
\hline 122 & 2 & US: All Employees: Mining (SA, Thous) \\
\hline 123 & 2 & US: All Employees: Construction (SA, Thous) \\
\hline 124 & 2 & US: All Employees: Manufacturing (SA, Thous) \\
\hline 125 & 2 & US: All Employees: Durable Goods Manufacturing (SA, Thous) \\
\hline 126 & 2 & US: All Employees: Nondurable Goods Manufacturing (SA, Thous) \\
\hline 127 & 2 & $\begin{array}{l}\text { US: All Employees: Service-Producing Industries incl Government (SA, } \\
\text { Thous) }\end{array}$ \\
\hline 128 & 2 & US: All Employees: Trade, Transportation \& Utilities (SA, Thous) \\
\hline 129 & 2 & US: All Employees: Wholesale Trade (SA, Thous) \\
\hline 130 & 2 & US: All Employees: Retail Trade (SA, Thous) \\
\hline 131 & 2 & US: All Employees: Financial Activities (SA, Thous) \\
\hline 132 & 2 & US: All Employees: Government (SA, Thous) \\
\hline 133 & 2 & Civilians Unemployed for Less Than 5 Weeks (SA, Thous.) \\
\hline 134 & 2 & Civilians Unemployed for 5-14 Weeks (SA, Thous.) \\
\hline 135 & 2 & Civilians Unemployed for 15-26 Weeks (SA, Thous.) \\
\hline 136 & 2 & Civilians Unemployed for 27 Weeks and Over (SA, Thous.) \\
\hline 137 & 2 & Civilian Labor Force: 16 yr + (SA, Thous) \\
\hline 138 & 2 & US: Unemployed: 16 Years \& Over (SA, Thous) \\
\hline 139 & 0 & US: Civilian Unemployment Rate (SA, \%) \\
\hline 140 & 2 & Housing Starts (SAAR, Thous.Units) \\
\hline 141 & 2 & Housing Starts: Northeast (SAAR, Thous.Units) \\
\hline 142 & 2 & Housing Starts: Midwest (SAAR, Thous.Units) \\
\hline 143 & 2 & Housing Starts: South (SAAR, Thous.Units) \\
\hline 144 & 2 & Housing Starts: West (SAAR, Thous.Units) \\
\hline 145 & 0 & Housing Authorized, Not Started: US (EOP, NSA, Thous.Units) \\
\hline 146 & 2 & Manufacturers' Shipments of Mobile Homes (SAAR, Thous.Units) \\
\hline 147 & 0 & ISM Mfg: Inventories Index (SA, 50+ = Econ Expand) \\
\hline
\end{tabular}


Table 2: Data

\begin{tabular}{|c|c|c|}
\hline Index & Transformation & Description \\
\hline 148 & 0 & ISM Mfg: New Orders Index (SA, $50+=$ Econ Expand) \\
\hline 149 & 0 & ISM Mfg: Supplier Deliveries Index (SA, $50+=$ Slower) \\
\hline 150 & 2 & Stock Price Index: NYSE Composite (Avg, Dec-31-02=5000) \\
\hline 151 & 2 & Stock Price Index: Standard \& Poor's 500 Composite $(1941-43=10)$ \\
\hline 152 & 2 & Stock Price Index: Standard \& Poor's 500 Industrials $(1941-43=10)$ \\
\hline 153 & 2 & Shiller Cyclically Adjusted S\&P Price to Earnings Ratio (Ratio) \\
\hline 154 & 0 & S\&P 500 Composite Price/Operating Earnings Ratio (Ratio) \\
\hline 155 & 0 & Federal Funds [effective] Rate (\% p.a.) \\
\hline 156 & 0 & 3-Month Treasury Bill Market Bid Yield at Constant Maturity (\%) \\
\hline 157 & 0 & 6-Month Treasury Bill Market Bid Yield at Constant Maturity (\%) \\
\hline 158 & 0 & 1-Year Treasury Bill Yield at Constant Maturity (\%) \\
\hline 159 & 0 & 5-Year Treasury Note Yield at Constant Maturity (\%) \\
\hline 160 & 0 & 10-Year Treasury Bond Yield at Constant Maturity (\%) \\
\hline 161 & 0 & Moody's Seasoned Aaa Corporate Bond Yield (\% p.a.) \\
\hline 162 & 0 & Moody's Seasoned Baa Corporate Bond Yield (\% p.a.) \\
\hline 163 & 0 & SPREAD1 \\
\hline 164 & 0 & SPREAD2 \\
\hline 165 & 0 & SPREAD3 \\
\hline 166 & 0 & SPREAD4 \\
\hline 167 & 0 & SPREAD5 \\
\hline 168 & 0 & SPREAD6 \\
\hline 169 & 2 & Money Stock: M1 (SA, Bil.\$) \\
\hline 170 & 2 & Money Stock: M2 (SA, Bil.\$) \\
\hline 171 & 0 & Velocity of Money: Ratio of Nominal GDP to Money Supply M2 (Ratio) \\
\hline 172 & 2 & Commercial Paper Outstanding: Nonfinancial Issuers (SA, Bil.\$) \\
\hline 173 & 2 & C \& I Loans in Bank Credit: All Commercial Banks (SA, Bil.\$) \\
\hline 174 & 2 & Revolving Consumer Credit Outstanding (EOP, SA, Bil.\$) \\
\hline 175 & 2 & PPI: Finished Goods $(\mathrm{SA}, 1982=100)$ \\
\hline 176 & 2 & PPI: Finished Consumer Goods (SA, 1982=100) \\
\hline 177 & 2 & PPI: Intermediate Materials, Supplies and Components (SA, 1982=100) \\
\hline 178 & 2 & PPI: Crude Materials for Further Processing $(\mathrm{SA}, 1982=100)$ \\
\hline 179 & 2 & CPI-U: All Items (SA, 1982-84=100) \\
\hline 180 & 2 & CPI-U: Apparel Less Footwear (SA, 1982-84=100) \\
\hline 181 & 2 & CPI-U: Transportation (SA, 1982-84=100) \\
\hline 182 & 2 & CPI-U: Medical Care (SA, 1982-84=100) \\
\hline 183 & 2 & CPI-U: Commodities (SA, 1982-84=100) \\
\hline 184 & 2 & CPI-U: Durables (SA, 1982-84=100) \\
\hline 185 & 2 & CPI-U: Services (SA, 1982-84=100) \\
\hline 186 & 2 & CPI-U: All Items Less Food (SA, 1982-84=100) \\
\hline 187 & 2 & CPI-U: All Items Less Shelter (SA, 1982-84=100) \\
\hline 188 & 2 & CPI-U: All Items Less Medical Care (SA, 1982-84=100) \\
\hline 189 & 2 & Avg Hourly Earnings: Prod \& Nonsupervisory: Construction (SA, \$/Hr) \\
\hline 190 & 2 & Avg Hourly Earnings: Prod \& Nonsupervisory: Manufacturing (SA, $\$ / \mathrm{Hr}$ ) \\
\hline 191 & 0 & University of Michigan: Consumer Expectations (NSA, Q1-66=100) \\
\hline 192 & 2 & Gross Domestic Product (SAAR, Bil.\$) \\
\hline 193 & 2 & Personal Consumption Expenditures: Durable Goods (SAAR, Bil.\$) \\
\hline 194 & 2 & Personal Consumption Expenditures: Nondurable Goods (SAAR, Bil.\$) \\
\hline 195 & 2 & Personal Consumption Expenditures: Services (SAAR, Bil.\$) \\
\hline 196 & 2 & Private Nonresidential Fixed Investment (SAAR, Bil.\$) \\
\hline 197 & 2 & Private Residential Investment (SAAR,Bil.\$) \\
\hline 198 & 2 & Exports of Goods (SAAR, Bil.\$) \\
\hline 199 & 2 & Exports of Services (SAAR, Bil.\$) \\
\hline 200 & 2 & Imports of Goods (SAAR, Bil.\$) \\
\hline 201 & 2 & Imports of Services (SAAR, Bil.\$) \\
\hline 202 & 2 & National Defense Consumption \& Gross Investment (SAAR, Bil.\$) \\
\hline 203 & 2 & $\begin{array}{l}\text { Federal Government Nondefense Consumption \& Gross Investment } \\
\text { (SAAR, Bil.\$) }\end{array}$ \\
\hline 204 & 2 & US: S\&P/CASE-SHILLER HOME PRICE INDEX ,SA \\
\hline
\end{tabular}


Table 2: Data

\begin{tabular}{lll}
\hline Index & Transformation & Description \\
\hline 205 & 0 & US Shadow Rate
\end{tabular}

